\title{
Journal of the International Society

\section{International Society of Sports Nutrition position stand: creatine supplementation and exercise}

Thomas W Buford, Richard B Kreider*, Jeffrey R Stout, Mike Greenwood, Bill Campbell, Marie Spano, Tim Ziegenfuss, Hector Lopez, Jamie Landis and Jose Antonio

Address: International Society of Sports Nutrition, 600 Pembrook Drive, Woodland Park, CO 80863, USA

Email: Thomas W Buford - thomas_buford@baylor.edu; Richard B Kreider* - Richard_Kreider@baylor.edu; Jeffrey R Stout - jrstout@ou.edu; Mike Greenwood - Mike_Greenwood@baylor.edu; Bill Campbell - Campbell@coedu.usf.edu; Marie Spano - mariespano@comcast.net; Tim Ziegenfuss - tim@ohioresearchgroup.com; Hector Lopez - hlopezmd@gmail.com; Jamie Landis - jlandis@lakelandcc.edu; Jose Antonio - exphys@aol.com

* Corresponding author

Published: 30 August 2007

Journal of the International Society of Sports Nutrition 2007, 4:6 doi: I0.I 186/I550-2783-46

This article is available from: http://www.jissn.com/content/4/I/6

(C) 2007 Buford et al; licensee BioMed Central Ltd.

This is an Open Access article distributed under the terms of the Creative Commons Attribution License (http://creativecommons.org/licenses/by/2.0), which permits unrestricted use, distribution, and reproduction in any medium, provided the original work is properly cited.
Received: 13 August 2007

Accepted: 30 August 2007

\section{A Position Statement and Review of the Literature}

Position Statement: The following nine points related to the use of creatine as a nutritional supplement constitute the Position Statement of the Society. They have been approved by the Research Committee of the Society.

1. Creatine monohydrate is the most effective ergogenic nutritional supplement currently available to athletes in terms of increasing high-intensity exercise capacity and lean body mass during training.

2. Creatine monohydrate supplementation is not only safe, but possibly beneficial in regard to preventing injury and/or management of select medical conditions when taken within recommended guidelines.

3. There is no scientific evidence that the short- or longterm use of creatine monohydrate has any detrimental effects on otherwise healthy individuals.

4. If proper precautions and supervision are provided, supplementation in young athletes is acceptable and may provide a nutritional alternative to potentially dangerous anabolic drugs.
5. At present, creatine monohydrate is the most extensively studied and clinically effective form of creatine for use in nutritional supplements in terms of muscle uptake and ability to increase high-intensity exercise capacity.

6 . The addition of carbohydrate or carbohydrate and protein to a creatine supplement appears to increase muscular retention of creatine, although the effect on performance measures may not be greater than using creatine monohydrate alone.

7. The quickest method of increasing muscle creatine stores appears to be to consume $\sim 0.3$ grams $/ \mathrm{kg} /$ day of creatine monohydrate for at least 3 days followed by $3-5 \mathrm{~g} /$ $\mathrm{d}$ thereafter to maintain elevated stores. Ingesting smaller amounts of creatine monohydrate (e.g., 2-3 g/d) will increase muscle creatine stores over a 3-4 week period, however, the performance effects of this method of supplementation are less supported.

8. Creatine products are readily available as a dietary supplement and are regulated by the U.S. Food and Drug Administration (FDA). Specifically, in 1994, U.S. President Bill Clinton signed into law the Dietary Supplement Health and Education Act (DSHEA). DSHEA allows manufacturers/companies/brands to make structure-function 
claims; however, the law strictly prohibits disease claims for dietary supplements.

9. Creatine monohydrate has been reported to have a number of potentially beneficial uses in several clinical populations, and further research is warranted in these areas.

The following literature review has been prepared by the authors in support of the aforementioned position statement.

\section{Creatine Supplementation and Exercise: A Review of the Literature Introduction}

The use of creatine as a sport supplement has been surrounded by both controversy and fallacy since it gained widespread popularity in the early 1990's. Anecdotal and media reports have often claimed that creatine usage is a dangerous and unnecessary practice; often linking creatine use to anabolic steroid abuse [1]. Many athletes and experts in the field have reported that creatine supplementation is not only beneficial for athletic performance and various medical conditions but is also clinically safe [2-5]. Although creatine has recently been accepted as a safe and useful ergogenic aid, several myths have been purported about creatine supplementation which include:

1. All weight gained during supplementation is due to water retention.

\section{Creatine supplementation causes renal distress.}

3. Creatine supplementation causes cramping, dehydration, and/or altered electrolyte status.

4. Long-term effects of creatine supplementation are completely unknown.

5. Newer creatine formulations are more beneficial than creatine monohydrate $(\mathrm{CM})$ and cause fewer side effects.

6. It's unethical and/or illegal to use creatine supplements.

While these myths have been refuted through scientific investigation, the general public is still primarily exposed to the mass media which may or may not have accurate information. Due to this confounding information, combined with the fact that creatine has become one of the most popular nutritional supplements on the market, it is important to examine the primary literature on supplemental creatine ingestion in humans. The purpose of this review is to determine the present state of knowledge concerning creatine supplementation, so that reasonable guidelines may be established and unfounded fears diminished in regard to its use.

\section{Background}

Creatine has become one of the most extensively studied and scientifically validated nutritional ergogenic aids for athletes. Additionally, creatine has been evaluated as a potential therapeutic agent in a variety of medical conditions such as Alzheimer's and Parkinson's diseases. Biochemically speaking, the energy supplied to rephosphorylate adenosine diphosphate (ADP) to adenosine triphosphate (ATP) during and following intense exercise is largely dependent on the amount of phosphocreatine (PCr) stored in the muscle [6,7]. As PCr stores become depleted during intense exercise, energy availability diminishes due to the inability to resynthesize ATP at the rate required to sustained high-intensity exercise $[6,7]$. Consequently, the ability to maintain maximal-effort exercise declines. The availability of $\mathrm{PCr}$ in the muscle may significantly influence the amount of energy generated during brief periods of high-intensity exercise. Furthermore, it has been hypothesized that increasing muscle creatine content, via creatine supplementation, may increase the availability of PCr allowing for an accelerated rate of resynthesis of ATP during and following highintensity, short-duration exercise [6-12]. Theoretically, creatine supplementation during training may lead to greater training adaptations due to an enhanced quality and volume of work performed. In terms of potential medical applications, creatine is intimately involved in a number of metabolic pathways. For this reason, medical researchers have been investigating the potential therapeutic role of creatine supplementation in a variety of patient populations.

Creatine is chemically known as a non-protein nitrogen; a compound which contains nitrogen but is not a protein per se [13]. It is synthesized in the liver and pancreas from the amino acids arginine, glycine, and methionine $[9,13,14]$. Approximately $95 \%$ of the body's creatine is stored in skeletal muscle. Additionally, small amounts of creatine are also found in the brain and testes $[8,15]$. About two thirds of the creatine found in skeletal muscle is stored as phosphocreatine (PCr) while the remaining amount of creatine is stored as free creatine [8]. The total creatine pool ( $\mathrm{PCr}+$ free creatine) in skeletal muscle averages about 120 grams for a $70 \mathrm{~kg}$ individual. However, the average human has the capacity to store up to 160 grams of creatine under certain conditions [7,9]. The body breaks down about $1-2 \%$ of the creatine pool per day (about 1-2 grams/day) into creatinine in the skeletal muscle [13]. The creatinine is then excreted in urine $[13,16]$. Creatine stores can be replenished by obtaining creatine in the diet or through endogenous synthesis of creatine from glycine, arginine, and methionine $[17,18]$. 
Dietary sources of creatine include meats and fish. Large amounts of fish and meat must be consumed in order to obtain gram quantities of creatine. Whereas dietary supplementation of creatine provides an inexpensive and efficient means of increasing dietary availability of creatine without excessive fat and/or protein intake.

\section{Supplementation Protocols and Effects on Muscle Creatine Stores}

Various supplementation protocols have been suggested to be efficacious in increasing muscle stores of creatine. The amount of increase in muscle storage depends on the levels of creatine in the muscle prior to supplementation. Those who have lower muscle creatine stores, such as those who eat little meat or fish, are more likely to experience muscle storage increases of $20-40 \%$, whereas those with relatively high muscle stores may only increase stores by $10-20 \%$ [19]. The magnitude of the increase in skeletal muscle creatine content is important because studies have reported performance changes to be correlated to this increase $[20,21]$.

The supplementation protocol most often described in the literature is referred to as the "loading" protocol. This protocol is characterized by ingesting approximately 0.3 grams $/ \mathrm{kg} /$ day of CM for $5-7$ days (e.g., $\simeq 5$ grams taken four times per day) and 3-5 grams/day thereafter [18,22]. Research has shown a $10-40 \%$ increase in muscle creatine and PCr stores using this protocol $[10,22]$. Additional research has reported that the loading protocol may only need to be 2-3 days in length to be beneficial, particularly if the ingestion coincides with protein and/or carbohydrate $[23,24]$. Furthermore, supplementing with 0.25 grams/kg-fat free mass/day of CM may be an alternative dosage sufficient to increase muscle creatine stores [25].

Other suggested supplementation protocols utilized include those with no loading phase as well as "cycling" strategies. A few studies have reported protocols with no loading period to be sufficient for increasing muscle creatine ( $3 \mathrm{~g} / \mathrm{d}$ for 28 days) [15] as well as muscle size and strength ( $6 \mathrm{~g} / \mathrm{d}$ for 12 weeks) $[26,27]$. These protocols seems to be equally effective in increasing muscular stores of creatine, but the increase is more gradual and thus the ergogenic effect does not occur as quickly. Cycling protocols involve the consumption of "loading" doses for 3-5 days every 3 to 4 weeks $[18,22]$. These cycling protocols appear to be effective in increasing and maintaining muscle creatine content before a drop to baseline values, which occurs at about 4-6 weeks [28,29].

\section{Creatine Formulations and Combinations}

Many forms of creatine exist in the marketplace, and these choices can be very confusing for the consumer. Some of these formulations and combinations include creatine phosphate, creatine $+\beta$-hydroxy- $\beta$-methlybutyrate $(\mathrm{HMB})$, creatine + sodium bicarbonate, creatine magnesium-chelate, creatine + glycerol, creatine + glutamine, creatine $+\beta$-alanine, creatine ethyl ester, creatine with cinnulin extract, as well as "effervescent" and "serum formulations". Most of these forms of creatine have been reported to be no better than traditional $\mathrm{CM}$ in terms of increasing strength or performance [30-38]. Reliable studies are yet to be published for creatine ethyl ester and creatine with cinnulin extract. Recent studies do suggest, however, that adding $\beta$-alanine to $\mathrm{CM}$ may produce greater effects than $\mathrm{CM}$ alone. These investigations indicate that the combination may have greater effects on strength, lean mass, and body fat percentage; in addition to delaying neuromuscular fatigue $[31,32]$.

Three alternative creatine formulations have shown promise, but at present do not have sufficient evidence to warrant recommendation in lieu of CM. For example, creatine phosphate has been reported to be as effective as CM at improving LBM and strength, [36] yet this has only been reported in one study. In addition, creatine phosphate is currently more difficult and expensive to produce than CM. Combining CM with sodium phosphate, which has been reported to enhance high-intensity endurance exercise, may be a more affordable alternative to creatine phosphate. Secondly, a creatine/HMB combination was reported to be more effective at improving LBM and strength than either supplement alone [39], but other data has reported the combination offers no benefit in terms of increasing aerobic or anaerobic capacity $[40,41]$. The conflicting data therefore do not warrant recommendation of the creatine/HMB combination in lieu of CM. Lastly, creatine + glycerol has been reported to increase total body water as a hyper-hydration method prior to exercise in the heat, but this is also the first study of its kind. In addition, this combination failed to improve thermal and cardiovascular responses to a greater extent than CM alone [42].

The addition of nutrients that increase insulin levels and/ or improve insulin sensitivity has been a major source of interest in the last few years by scientists looking to optimize the ergogenic effects of creatine. The addition of certain macronutrients appears to significantly augment muscle retention of creatine. Green et al. [24] reported that adding $93 \mathrm{~g}$ of carbohydrate to $5 \mathrm{~g}$ of $\mathrm{CM}$ increased total muscle creatine by 60\%. Likewise, Steenge et al. [23] reported that adding $47 \mathrm{~g}$ of carbohydrate and $50 \mathrm{~g}$ of protein to $\mathrm{CM}$ was as effective at promoting muscle retention of creatine as adding $96 \mathrm{~g}$ of carbohydrate. Additional investigations by Greenwood and colleagues $[30,43]$ have reported increased creatine retention from the addition of dextrose or low levels of D-pinitol (a plant extract with insulin-like properties). While the addition of these nutrients has proved to increase muscle retention, several 
recent investigations have reported these combinations to be no more effective at improving muscle strength and endurance or athletic performance [44-46]. Other recent studies, however, have indicated a potential benefit on anaerobic power, muscle hypertrophy, and 1 RM muscle strength when combining protein with creatine $[47,48]$. It appears that combining CM with carbohydrate or carbohydrate and protein produces optimal results. Studies suggest that increasing skeletal muscle creatine uptake may enhance the benefits of training.

\section{Effects of Supplementation on Exercise Performance and Training Adaptations}

CM appears to be the most effective nutritional supplement currently available in terms of improving lean body mass and anaerobic capacity. To date, several hundred peer-reviewed research studies have been conducted to evaluate the efficacy of CM supplementation in improving exercise performance. Nearly $70 \%$ of these studies have reported a significant improvement in exercise capacity, while the others have generally reported non-significant gains in performance [49]. No studies have reported an ergolytic effect on performance although some have suggested that weight gain associated with CM supplementation could be detrimental in sports such as running or swimming. The average gain in performance from these studies typically ranges between 10 to $15 \%$ depending on the variable of interest. For example, shortterm CM supplementation has been reported to improve maximal power/strength (5-15\%), work performed during sets of maximal effort muscle contractions (5-15\%), single-effort sprint performance (1-5\%), and work performed during repetitive sprint performance (5-15\%) [49]. Long-term CM supplementation appears to enhance the overall quality of training, leading to 5 to $15 \%$ greater gains in strength and performance [49]. Nearly all studies indicate that "proper" CM supplementation increases body mass by about 1 to $2 \mathrm{~kg}$ in the first week of loading [19].

The vast expanse of literature confirming the effectiveness of CM supplementation is far beyond the scope of this review. Briefly, short-term adaptations reported from CM supplementation include increased cycling power, total work performed on the bench press and jump squat, as well as improved sport performance in sprinting, swimming, and soccer [38,50-57]. Long-term adaptations when combining $\mathrm{CM}$ supplementation with training include increased muscle creatine and $\mathrm{PCr}$ content, lean body mass, strength, sprint performance, power, rate of force development, and muscle diameter [39,54-60]. In long-term studies, subjects taking CM typically gain about twice as much body mass and/or fat free mass (i.e., an extra 2 to 4 pounds of muscle mass during 4 to 12 weeks of training) than subjects taking a placebo [61-64]. The gains in muscle mass appear to be a result of an improved ability to perform high-intensity exercise via increased $\mathrm{PCr}$ availability and enhanced ATP synthesis, thereby enabling an athlete to train harder and promote greater muscular hypertrophy via increased myosin heavy chain expression possibly due to an increase in myogenic regulatory factors myogenin and MRF-4 $[26,27,65]$. The tremendous numbers of investigations conducted with positive results from CM supplementation lead us to conclude that it is the most effective nutritional supplement available today for increasing high-intensity exercise capacity and building lean mass.

\section{Medical Safety of Creatine Supplementation}

While the only clinically significant side effect reported in the research literature is that of weight gain $[4,18,22]$, many anecdotal claims of side effects including dehydration, cramping, kidney and liver damage, musculoskeletal injury, gastrointestinal distress, and anterior (leg) compartment syndrome still exist in the media and popular literature. While athletes who are taking CM may experience these symptoms, the scientific literature suggests that these athletes have no greater, and a possibly lower, risk of these symptoms than those not supplementing with CM $[2,4,66,67]$.

Many of these fears have been generated by the media and data taken from case studies $(n=1)$. Poortmans and Francaux reported that the claims of deleterious effects of creatine supplements on renal function began in 1998 [68]. These claims followed a report that creatine supplementation was detrimental to renal glomerular filtration rate (GFR) in a 25-year-old man who had previously presented with kidney disease (glomerulosclerosis and corticosteroid-responsive nephritic syndrome) [69]. Three days later, a French sports newspaper, L'Equipe, reported that supplemental creatine is dangerous for the kidneys in any condition [70]. Several European newspapers then picked up the "news" and reported the same. Since that time, other individual case studies have been published posing that CM supplementation caused deleterious effects on renal function $[71,72]$.

Much of the concern about CM supplementation and renal function has centered around concerns over increased serum creatinine levels. While creatinine does make up a portion of GFR and must be excreted by the kidneys, there is no evidence to support the notion that normal creatine intakes $(<25 \mathrm{~g} / \mathrm{d})$ in healthy adults cause renal dysfunction. In fact, Poortmans et al. have shown no detrimental effects of short- (5 days), medium- (14 days), or long-term (10 months to 5 years) CM supplementation on renal function $[5,73,74]$. Interestingly, Kreider et al. [4] observed no significant difference in creatinine levels between CM users and controls, yet most athletes (regard- 
less of whether taking $\mathrm{CM}$ or not) had elevated creatinine levels along with proper clearance during intense training. The authors noted that if serum creatinine was examined as the sole measure of renal function, it would appear that nearly all of the athletes (regardless of CM usage) were experiencing renal distress. Although case studies have reported problems, these large-scale, controlled studies have shown no evidence indicating that CM supplementation in healthy individuals is a detriment to kidney functioning.

Another anecdotal complaint about supplemental creatine is that the long-term effects are not known. Widespread use of CM began in the 1990's. Over the last few years a number of researchers have begun to release results of long-term safety trials. So far, no long-term side effects have been observed in athletes (up to 5 years), infants with creatine synthesis deficiency (up to 3 years), or in clinical patient populations (up to 5 years) $[4,5,18,75,76]$. One cohort of patients taking $1.5-3$ grams/day of CM has been monitored since 1981 with no significant side effects $[77,78]$. In addition, research has demonstrated a number of potentially helpful clinical uses of CM in heart patients, infants and patients with creatine synthesis deficiency, patients suffering orthopedic injury, and patients with various neuromuscular diseases. Potential medical uses of supplemental creatine have been investigated since the mid 1970s. Initially, research focused on the role of $\mathrm{CM}$ and/or creatine phosphate in reducing heart arrhythmias and/or improving heart function during ischemic events [18]. Interest in medical uses of creatine supplements has expanded to include those with creatine deficiencies [79-81], brain and/or spinal cord injuries [82-86], muscular dystrophy [87-90], diabetes [91], high cholesterol/triglyceride levels [92], and pulmonary disease [93] among others. Although more research is needed to determine the extent of the clinical utility, some promising results have been reported in a number of studies suggesting that creatine supplements may have therapeutic benefit in certain patient populations. In conjunction with short- and long-term studies in healthy populations, this evidence suggests that creatine supplementation appears to be safe when taken within recommended usage guidelines.

\section{Creatine Use in Children and Adolescents}

Opponents of creatine supplementation have claimed that it is not safe for children and adolescents [1]. While fewer investigations have been conducted in using younger participants, no study has shown $\mathrm{CM}$ to have adverse effects in children. In fact, long-term CM supplementation (e.g., $4-8$ grams/day for up to 3 years) has been used as an adjunctive therapy for a number of creatine synthesis deficiencies and neuromuscular disorders in children. Clinical trials are also being conducted in chil- dren with Duschenne muscular dystrophy $[87,88]$. However, as less is known about the effects of supplemental creatine on children and adolescents, it is the view of the ISSN that younger athletes should consider a creatine supplement only if the following conditions are met [19]:

1. The athlete is past puberty and is involved in serious/ competitive training that may benefit from creatine supplementation;

2. The athlete is eating a well-balanced, performanceenhancing diet;

3. The athlete and his/her parents understand the truth concerning the effects of creatine supplementation;

4. The athlete's parents approve that their child takes supplemental creatine;

5. Creatine supplementation can be supervised by the athletes parents, trainers, coaches, and/or physician;

6. Quality supplements are used; and,

7. The athlete does not exceed recommended dosages.

If these conditions are met, then it would seem reasonable that high school athletes should be able to take a creatine supplement. Doing so may actually provide a safe nutritional alternative to illegal anabolic steroids or other potentially harmful drugs. Conversely, if the above conditions are not met, then creatine supplementation may not be appropriate. It appears that this is no different than teaching young athletes' proper training and dietary strategies to optimize performance. Creatine is not a panacea or short cut to athletic success. It can, however, offer some benefits to optimize training of athletes involved in intense exercise in a similar manner that ingesting a highcarbohydrate diet, sports drinks, and/or carbohydrate loading can optimize performance of an endurance athlete.

\section{The Ethics of Creatine}

Several athletic governing bodies and special interest groups have questioned whether it is ethical for athletes to take creatine supplements as a method of enhancing performance. Since research indicates that $\mathrm{CM}$ can improve performance, and it would be difficult to ingest enough creatine from food in the diet, they rationalize that it is unethical to do so. In this age of steroid suspicion in sports, some argue that if you allow athletes to take creatine, they may be more predisposed to try other dangerous supplements and/or drugs. Still others have attempted to directly lump creatine in with anabolic steroids and/or banned stimulants and have called for a ban on the use of 
$\mathrm{CM}$ and other supplements among athletes. Finally, fresh off of the ban of dietary supplements containing ephedra, some have called for a ban on the sale of CM citing safety concerns. Creatine supplementation is not currently banned by any athletic organization although the NCAA does not allow institutions to provide CM or other "muscle building" supplements to their athletes (e.g., protein, amino acids, HMB, etc). In this case, athletes must purchase creatine containing supplements on their own. The International Olympic Committee considered these arguments and ruled that there was no need to ban creatine supplements since creatine is readily found in meat and fish and there is no valid test to determine whether athletes are taking it. In light of the research that has been conducted with CM, it appears that those who call for a ban on it are merely familiar with the anecdotal myths surrounding the supplement, and not the actual facts. We see no difference between creatine supplementation and ethical methods of gaining athletic advantage such as using advanced training techniques and proper nutritional methods. Carbohydrate loading is a nutritional technique used to enhance performance by enhancing glycogen stores. We see no difference between such a practice and supplementing with creatine to enhance skeletal muscle creatine and PCr stores. If anything, it could be argued that banning the use of creatine would be unethi$\mathrm{cal}$ as it has been reported to decrease the incidence of musculoskeletal injuries $[2,66,75,94]$, heat stress $[2,95,96], \quad$ provide neuroprotective effects $[82,83,85,97,98]$, and expedite rehabilitation from injury $[86,99,100]$.

\section{Conclusion}

It is the position of the International Society of Sports Nutrition that the use of creatine as a nutritional supplement within established guidelines is safe, effective, and ethical. Despite lingering myths concerning creatine supplementation in conjunction with exercise, CM remains one of the most extensively studied, as well as effective, nutritional aids available to athletes. Hundreds of studies have shown the effectiveness of CM supplementation in improving anaerobic capacity, strength, and lean body mass in conjunction with training. In addition, $\mathrm{CM}$ has repeatedly been reported to be safe, as well as possibly beneficial in preventing injury. Finally, the future of creatine research looks bright in regard to the areas of transport mechanisms, improved muscle retention, as well as treatment of numerous clinical maladies via supplementation.

\section{References}

I. Metzl JD, Small E, Levine SR, Gershel JC: Creatine use among young athletes. Pediatrics 200I, 108:42I-425.

2. Greenwood M, Kreider RB, Melton C, Rasmussen C, Lancaster S, Cantler E, Milnor P, Almada A: Creatine supplementation during college football training does not increase the incidence of cramping or injury. Mol Cell Biochem 2003, 244:83-88.
3. Kreider RB: Creatine supplementation: analysis of ergogenic value, medical safety, and concerns. J Exerc Physiol Online 1998, I:.

4. Kreider RB, Melton C, Rasmussen CJ, Greenwood M, Lancaster S, Cantler EC, Milnor P, Almada AL: Long-term creatine supplementation does not significantly affect clinical markers of health in athletes. Mol Cell Biochem 2003, 244:95-104.

5. Poortmans JR, Francaux M: Long-term oral creatine supplementation does not impair renal function in healthy athletes. Med Sci Sports Exerc 1999, 3 I: I I08-I I I0.

6. Chanutin A: The fate of creatine when administered to man. J Biol Chem 1926, 67:29-34.

7. Hultman E, Bergstrom J, Spreit L, Soderlund K: Energy metabolism and fatigue. In Biochemistry of Exercise VII Edited by: Taylor A, Gollnick PD, Green H. Human Kinetics: Champaign, IL; 1990:73-92.

8. Balsom PD, Soderlund K, Ekblom B: Creatine in humans with special reference to creatine supplementation. Sports Med 1994, 18:268-80.

9. Greenhaff $P$ : The nutritional biochemistry of creatine. J Nutrit Biochem 1997, I I:610-618.

10. Greenhaff PL: Muscle creatine loading in humans: Procedures and functional and metabolic effects. 6th Internationl Conference on Guanidino Compounds in Biology and Medicine. Cincinatti, $\mathrm{OH} 200 \mathrm{I}$.

II. Greenhaff P, Casey A, Green AL: Creatine supplementation revisited: An update. Insider 1996, 4:I-2.

12. Harris RC, Soderlund K, Hultman E: Elevation of creatine in resting and exercised muscle of normal subjects by creatine supplementation. Clin Sci (Colch) 1992, 83(3):367-374.

13. Brunzel NA: Renal function: Nonprotein nitrogen compounds, function tests, and renal disease. In Clinical Chemistry Edited by: Scardiglia J, Brown M, McCullough K, Davis K. McGraw-Hill: New York, NY; 2003:373-399.

14. Paddon-Jones D, Borsheim E, Wolfe RR: Potential ergogenic effects of arginine and creatine supplementation. J Nutr 2004 134:2888S-2894S.

15. Hultman E, Soderlund K, Timmons JA, Cederblad G, Greenhaff PL: Muscle creatine loading in men. I Appl Physiol 1996, 81:232-237.

16. Burke DG, Smith-Palmer T, Holt LE, Head B, Chilibeck PD: The effect of 7 days of creatine supplementation on 24-hour urinary creatine excretion. J Strength Cond Res 200I, 15:59-62.

17. Williams $M H$, Branch JD: Creatine supplementation and exercise performance: an update. J Am Coll Nutr 1998, 17:216-34.

18. Williams MH, Kreider R, Branch JD: Creatine: The power supplement. Champaign, IL: Human Kinetics Publishers; 1999:252.

19. Kreider RB: Creatine in Sports. In Essentials of Sport Nutrition \& Supplements Edited by: Antonio J, Kalman D, Stout J, et al. Humana Press Inc., Totowa, Nj; 2007 in press.

20. Greenhaff PL, Casey A, Short AH, Harris R, Soderlund K, Hultman E: Influence of oral creatine supplementation of muscle torque during repeated bouts of maximal voluntary exercise in man. Clin Sci (Colch) 1993, 84(5):565-57I.

21. Greenhaff PL, Bodin K, Soderlund K, Hultman E: Effect of oral creatine supplementation on skeletal muscle phosphocreatine resynthesis. Am J Physiol 1994, 266:E725-30.

22. Kreider RB, Leutholtz BC, Greenwood M: Creatine. In Nutritional Ergogenic Aids Edited by: Wolinsky I, Driskel J. CRC Press LLC: Boca Raton, FL; 2004:8I-I04

23. Steenge GR, Simpson EJ, Greenhaff PL: Protein- and carbohydrate-induced augmentation of whole body creatine retention in humans. J Appl Physiol 2000, 89: I I65-7I.

24. Green AL, Hultman E, Macdonald IA, Sewell DA, Greenhaff PL: Carbohydrate ingestion augments skeletal muscle creatine accumulation during creatine supplementation in humans. Am J Physiol 1996, 271:E821-6.

25. Burke DG, Chilibeck PD, Parise G, Candow DG, Mahoney D, Tarnopolsky M: Effect of creatine and weight training on muscle creatine and performance in vegetarians. Med Sci Sports Exerc 2003, 35: 1946-55.

26. Willoughby DS, Rosene J: Effects of oral creatine and resistance training on myosin heavy chain expression. Med Sci Sports Exerc 200I, 33:1674-8I.

27. Willoughby DS, Rosene JM: Effects of oral creatine and resistance training on myogenic regulatory factor expression. Med Sci Sports Exerc 2003, 35:923-929.

28. Vandenberghe K, Goris M, Van Hecke P, Van Leemputte M, Vangerven $L$, Hespel $P$ : Long-term creatine intake is beneficial to 
muscle performance during resistance training. J Appl Physiol 1997, 83:2055-63.

29. Candow DG, Chilibeck PD, Chad KE, Chrusch MJ, Davison KS, Burke DG: Effect of ceasing creatine supplementation while maintaining resistance training in older men. J Aging Phys Act 2004, 12:219-31.

30. Greenwood M, Kreider R, Earnest C, Rassmussen C, Almada A: Differences in creatine retention among three nutritional formulations of oral creatine supplements. J Exerc Physiol Online 2003, 6:37-43.

31. Stout JR, Cramer JT, Mielke M, O'Kroy J, Torok DJ, Zoeller RF: Effects of twenty-eight days of beta-alanine and creatine monohydrate supplementation on the physical working capacity at neuromuscular fatigue threshold. J Strength Cond Res 2006, 20:938-931.

32. Hoffman J, Ramatess N, Kang J, Mangine G, Faigenbaum A, Stout J: Effect of creatine and beta-alanine supplementation on performance and endocrine responses in strength/power athletes. Int J Sport Nutr Exerc Metab 2006, 16:430-446.

33. Falk DJ, Heelan KA, Thyfault JP, Koch AJ: Effects of effervescent creatine, ribose, and glutamine supplementation on muscular strength, muscular endurance, and body composition. J Strength Cond Res 2003, 17:810-816.

34. Kreider RB, Willoughby D, Greenwood M, Parise G, Payne E, Tarnopolsky M: Effects of serum creatine supplementation on muscle creatine and phosphagen levels. J Exerc Physio Online 2003, 6:24-33.

35. Selsby JT, DiSilvestro RA, Devor ST: $\mathbf{M g}^{2+}$-creatine chelate and a low-dose creatine supplementation regimen improve exercise performance. J Strength Cond Res 2004, I8:3 II-3 I5.

36. Peeters BM, Lantz CD, Mayhew JL: Effect of oral creatine monohydrate and creatine phosphate supplementation on maximal strength indices, body composition, and blood pressure. J Strength Cond Res 1999, 13:3-9.

37. Lehmkuhl M, Malone M, Justice B, Trone G, Pistilli E, Vinci D, Haff EE, Kilgore JL, Haff GG: The effects of 8 weeks of creatine monohydrate and glutamine supplementation on body composition and performance measures. J Strength Cond Res 2003, 17:425-438.

38. Mero AA, Keskinen KL, Malvela MT, Sallinen JM: Combined creatine and sodium bicarbonate supplementation enhances interval swimming. J Strength Cond Res 2004, 18:306-3I0.

39. Jowko E, Ostaszewski P, Jank M, Sacharuk J, Zieniewicz A, Wilczak J, Nissen S: Creatine and B-hydroxy-B-methylbutyrate (HMB) additively increase lean body mass and muscle strength during a weight-training program. Nutrition 200I, I7:558-566.

40. O'Conner DM, Crowe MJ: Effects of $\beta$-hydroxy- $\beta$-methylbutyrate and creatine monohydrate supplementation on the aerobic and anaerobic capacity of highly trained athletes. J Sports Med Phys Fitness 2003, 43:64-68.

4I. O'Conner DM, Crowe MJ: Effects of six weeks of beta-hydroxybeta-methylbutyrate (HMB) and HMB/creatine supplementation on strength, power, and anthropometry of highly trained athletes. J Strength Cond Res 2007, 21 : 41 9-423.

42. Easton C, Turner S, Pitsaladis YP: Creatine and glycerol hyperhydration in trained subjects before exercise in the heat. Int J Sports Nut Exerc Metab 2007, 17:70-91.

43. Greenwood M, Kreider RB, Rasmussen C, Almada AL, Earnest CP: D-pinitol augments whole body creatine retention in man. J Exerc Physiol Online 200I, 4:4I-47.

44. Chromiak JA, Smedley B, Carpenter W, Brown R, Koh YS, Lamberth JG, Joe LA, Abadie BR, Altorfer G: Effect of a I 0-week strength training program and recovery drink on body composition, muscular strength and endurance, and anaerobic power and capacity. Nutrition 2004, 20:420-427.

45. Carter JM, Bemben DA, Knehans AW, Bemben MG, Witten MS: Does nutritional supplementation influence adaptability of muscle to resistance training in men aged 48 to 72 years? J Geriatric Phys Therapy 2005, 28(2):40-47.

46. Theodorou AS, Havenetidis K, Zanker CL, O'Hara JP, King RF, Hood C, Paradisis G, Cooke CB: Effects of acute creatine loading with or without $\mathrm{CHO}$ on repeated bouts of maximal swimming in high-performance swimmers. I Strength Cond Res 2005, 19:265-269.

47. Beck TW, Housh T], Johnson GO, Coburn DW, Malek MH, Cramer JT: Effects of a drink containing creatine, amino acids, and protein, combined with ten weeks of resistance training on body composition, strength, and anaerobic performance. J Strength Cond Res 2007, 21:100-104.

48. Cribb PJ, Williams AD, Stathis CG, Carey MF, Hayes A: Effects of Whey Isolate, Creatine, and Resistance Training on Muscle Hypertrophy. Med Sci Sports Exer 2007, 39:298-307.

49. Kreider RB: Effects of creatine supplementation on performance and training adaptations. Mol Cell Biochem 2003, 244:89-94.

50. Volek JS, Kraemer WJ, Bush JA, Boetes M, Incledon T, Clark KL, Lynch JM: Creatine supplementation enhances muscular performance during high-intensity resistance exercise. J Am Diet Assoc 1997, 97:765-70.

51. Tarnopolsky MA, MacLennan DP: Creatine monohydrate supplementation enhances high-intensity exercise performance in males and females. Int J Sport Nutr Exerc Metab 2000, 10:452-63.

52. Wiroth JB, Bermon S, Andrei S, Dalloz E, Heberturne X, Dolisi C: Effects of oral creatine supplementation on maximal pedalling performance in older adults. Eur J Appl Physiol 200I, 84:533-9.

53. Skare OC, Skadberg, Wisnes AR: Creatine supplementation improves sprint performance in male sprinters. Scand J Med Sci Sports 200I, I I:96-102.

54. Mujika I, Padilla S, Ibanez J, Izquierdo M, Gorostiaga E: Creatine supplementation and sprint performance in soccer players. Med Sci Sports Exerc 2000, 32:518-25.

55. Ostojic SM: Creatine supplementation in young soccer players. Int J Sport Nutr Exerc Metab 2004, I 4:95-103.

56. Theodorou AS, Cooke CB, King RF, Hood C, Denison T, Wainwright BG, Havenitidis K: The effect of longer-term creatine supplementation on elite swimming performance after an acute creatine loading. J Sports Sci 1999, 17:853-9.

57. Preen D, Dawson B, Goodman C, Lawrence S, Beilby J, Ching S: Effect of creatine loading on long-term sprint exercise performance and metabolism. Med Sci Sports Exerc 200I, 33:8I 4-2I.

58. Vandenberghe K, Goris M, Van Hecke P, Van Leemputte M, Vangerven $L$, Hespel $P$ : Long-term creatine intake is beneficial to muscle performance during resistance training. I Appl Physiol 1997, 83:2055-63.

59. Kreider RB, Ferreira M, Wilson M, Grindstaff P, Plisk S, Reinardy J, Cantler E, Almada AL: Effects of creatine supplementation on body composition, strength, and sprint performance. Med $\mathrm{Sci}$ Sports Exerc 1998, 30:73-82.

60. Volek JS, Duncan ND, Mazzetti SA, Staron RS, Putukian M, Gomez AL, Pearson DR, Fink WJ, Kraemer WJ: Performance and muscle fiber adaptations to creatine supplementation and heavy resistance training. Med Sci Sports Exerc 1999, 3 I: I I 47-56.

6I. Stone MH, Sanborn K, Smith LL, O'Bryant HS, Hoke T, Utter AC, Johnson RL, Boros R, Hruby J, Pierce KC, Stone ME, Garner B: Effects of in-season (5 weeks) creatine and pyruvate supplementation on anaerobic performance and body composition in American football players. Int J Sport Nutr 1999, 9:146-65.

62. Noonan D, Berg K, Latin RW, Wagner JC, Reimers K: Effects of varying dosages of oral creatine relative to fat free body mass on strength and body composition. J Strength Cond Res 1998, 12:104-108.

63. Kirksey KB, Stone MH, Warren BJ, Johnson RL, Stone M, Haff GG Williams FE, Proulx C: The effects of 6 weeks of creatine monohydrate supplementation on performance measures and body composition in collegiate track and field athletes. Strength Cond Res 1999, 13:148-156.

64. Jones AM, Atter T, Georg KP: Oral creatine supplementation improves multiple sprint performance in elite ice-hockey players. J Sports Med Phys Fitness 1999, 39:189-96.

65. Kreider RB, Almada AL, Antonio J, Broeder C, Earnest C, Greenwood M, Incledon T, Kalman DS, Kleiner SM, Leutholtz B, Lowery LM, Mendel R, Stout JR, Willoughby DS, Ziegenfuss TN: ISSN exercise \& sport nutrition review: research and recommendations. Sport Nutr Rev J 2004, I: I-44.

66. Greenwood M, Kreider RB, Greenwood L, Byars A: Cramping and injury incidence in collegiate football players are reduced by creatine supplementation. J Athl Train 2003, 38:216-219.

67. Greenwood M, Kreider RB, Greenwood L, Byars A: The effects of creatine supplementation on cramping and injury occurrence during college baseball training and competition. Exerc Physiol Online 2003, 6: 16-23. 
68. Poortmans JR, Francaux M: Adverse effects of creatine supplementation: fact or fiction? Sports Med 2000, 30: I55-I70.

69. Pritchard NR, Kalra PA: Renal dysfunction accompanying oral creatine supplements. Lancet |998, 35 I: |252-| 253.

70. La creatine dangereuse? L'Equipe :10. 1998, April 10

7I. Koshy KM, Giswold E, Scheenberger EE: Interstitial nephritis in a patient taking creatine. N Engl J Med I999, 340:8I4-5.

72. Thorsteinsdottir B, Grande JP, Garovic VD: Acute renal failure in a young weight lifter taking multiple food supplements including creatine monohydrate. I Renal Nutr 2006, 16(4):341-345.

73. Poortmans JR, Auquier $H$, Renaut V, Durussel A, Saugy M, Brisson GR: Effect of short-term creatine supplementation on renal responses in men. Eur J Appl Physiol 1997, 76:566-567.

74. Poortmans JR, Kumps A, Duez P, Fofonka A, Carpentier A, Francaux $M$ : Effect of oral creatine supplementation on urinary methylamine, formaldehyde, and formate. Med Sci Sports Exerc 2005, 37:1717-1720.

75. Schilling BK, Stone MH, Utter A, Kearney JT, Johnson M, Coglianese R, Smith L, O'Bryant HS, Fry AC, Starks M, Keith R, Stone ME: Creatine supplementation and health variables: a retrospective study. Med Sci Sports Exerc 200I, 33:183-188.

76. Robinson TM, Sewell DA, Casey A, Steenge G, Greenhaff PL: Dietary creatine supplementation does not affect some haematological indices, or indices of muscle damage and hepatic and renal function. $\mathrm{Br}$ J Sports Med 2000, 34:284-8.

77. Sipila I, Rapola J, Simell O, Vannas A: Supplementary creatine as a treatment for gyrate atrophy of the choroid and retina. New Engl J Med I 98I, 304:867-870.

78. Vannas-Sulonen K, Sipila I, Vannas A, Simell O, Rapola J: Gyrate atrophy of the choroid and retina. A five-year follow-up of creatine supplementation. Ophthalmology 1985, 92:17|9-27.

79. Ensenauer R, Thiel T, Schwab KO, Tacke U, Stockler-lpsiroglu S, Schulze A, Hennig J, Lehnert W: Guanidinoacetate methyltransferase deficiency: differences of creatine uptake in human brain and muscle. Mol Genet Metab 2004, 82:208-13.

80. Schulze A, Ebinger F, Rating D, Mayatepek E: Improving treatment of guanidinoacetate methyltransferase deficiency: reduction of guanidinoacetic acid in body fluids by arginine restriction and ornithine supplementation. Mol Genet Metab 200I, 74:4I3-4I9.

81. Ganesan V, Johnson A, Connelly A, Eckhardt S, Surtees RA: Guanidinoacetate methyltransferase deficiency: new clinical features. Pediatr Neurol 1997, I7:155-157.

82. Zhu S, Li M, Figueroa BE, Liu A, Stavrovskaya IG, Pasinelli P, Beal MF, Brown RH Jr, Kristal BS, Ferrante RJ, Friedlander RM: Prophylactic creatine administration mediates neuroprotection in cerebral ischemia in mice. J Neurosci 2004, 24:5909-12.

83. Hausmann ON, Fouad K, Wallimann T, Schwab ME: Protective effects of oral creatine supplementation on spinal cord injury in rats. Spinal Cord 2002, 40:449-56.

84. Brustovetsky N, Brustovetsky T, Dubinsky JM: On the mechanisms of neuroprotection by creatine and phosphocreatine. J Neurochem 200I, 76:425-34

85. Sullivan PG, Geiger JD, Mattson MP, Scheff SW: Dietary supplement creatine protects against traumatic brain injury. Ann Neurol 2000, 48:723-9.

86. Jacobs PL, Mahoney ET, Cohn KA, Sheradsky LF, Green BA: Oral creatine supplementation enhances upper extremity work capacity in persons with cervical-level spinal cord injury. Arch Phys Med Rehabil 2002, 83: 19-23.

87. Felber S, Skladal D, Wyss M, Kremser C, Koller A, Sperl W: Oral creatine supplementation in Duchenne muscular dystrophy: a clinical and 3IP magnetic resonance spectroscopy study. Neurol Res 2000, 22: I45-50.

88. Tarnopolsky MA, Mahoney DJ, Vajsar J, Rodriguez C, Doherty TJ, Roy $\mathrm{BD}$, Biggar D: Creatine monohydrate enhances strength and body composition in Duchenne muscular dystrophy. Neurology 2004, 62: 177I-I777.

89. Pearlman JP, Fielding RA: Creatine Monohydrate as a therapeutic aid in muscular dystrophy. Nutr Reviews 2006, 64:80-88.

90. Matsumura T: A clinical trial of creatine monohydrate in muscular dystrophy patients. Clin Neurol (Japan) 2004, 44(10):66I-666.
91. Op't Eijnde B, Urso B, Richter EA, Greenhaff PL, Hespel P: Effect of oral creatine supplementation on human muscle GLUT4 protein content after immobilization. Diabetes 200I, 50:I8-23.

92. Earnest CP, Almada A, Mitchell TL: High-performance capillary electrophoresis-pure creatine monohydrate reduced blood lipids in men and women. Clinical Science 1996, 91:I I3-I I8.

93. Fuld JP, Kilduff LP, Neder JA, Pitsiladis Y, Lean MEJ, Ward SA, Cotton $M M$ : Creatine supplementation during pulmonary rehabilitation in chronic obstructive pulmonary disease. Thorax 2005, 60:53I-7.

94. Tyler TF, Nicholas SJ, Hershman EB, Glace BW, Mullaney MJ, McHugh MP: The effect of creatine supplementation on strength recovery after anterior cruciate ligament $(A C L)$ reconstruction: a randomized, placebo-controlled, double-blind trial. Am J Sports Med 2004, 32:383-8.

95. Kilduff LP, Georgiades E, James N, Minnion RH, Mitchell M, Kingsmore D, Hadjicharlambous M, Pitsiladis YP: The effects of creatine supplementation on cardiovascular, metabolic, and thermoregulatory responses during exercise in the heat in endurance-trained humans. Int J Sport Nutr Exerc Metab 2004, I 4:443-60.

96. Volek JS, Mazzetti SA, Farquhar WB, Barnes BR, Gomez AL, Kraemer W]: Physiological responses to short-term exercise in the heat after creatine loading. Med Sci Sports Exerc 200 I, 33: I I0I-8.

97. Wyss M, Schulze A: Health implications of creatine: can oral creatine supplementation protect against neurological and atherosclerotic disease? Neuroscience 2002, I I 2:243-60.

98. Ferrante RJ, Andreassen OA, Jenkins BG, Dedeoglu A, Kuemmerle S, Kubilus JK, Kaddurah-Daouk R, Hersch SM, Beal MF: Neuroprotective effects of creatine in a transgenic mouse model of Huntington's disease. J Neurosci 2000, 20:4389-97.

99. Tarnopolsky MA: Potential benefits of creatine monohydrate supplementation in the elderly. Curr Opin Clin Nutr Metab Care 2000, 3:497-502.

100. Hespel P, Op't Eijnde B, Van Leemputte M, Urso B, Greenhaff PL, Labarque V, Dymarkowski S, Van Hecke P, Richter EA: Oral creatine supplementation facilitates the rehabilitation of disuse atrophy and alters the expression of muscle myogenic factors in humans. J Physiol 200I, 536:625-33.
Publish with Bio Med Central and every scientist can read your work free of charge

"BioMed Central will be the most significant development for disseminating the results of biomedical research in our lifetime. "

Sir Paul Nurse, Cancer Research UK

Your research papers will be:

- available free of charge to the entire biomedical community

- peer reviewed and published immediately upon acceptance

- cited in PubMed and archived on PubMed Central

- yours - you keep the copyright
BiolMedcentral 